\title{
A Mini Review of Catalytic Reducing Nitrogen to Ammonia under Ambient Conditions
}

\author{
Jianjun Yang ${ }^{1,2 *}$ \\ ${ }^{1}$ Department of Chemical Engineering, School of Environmental Science and Engineering, China \\ ${ }^{2}$ Key Laboratory of Subsurface Hydrology and Ecological Effects in Arid Region Chang'an University, China
}

Submission: January 28, 2019 Published: February 26, 2019

"Corresponding author: Jianjun Yang, Department of Chemical Engineering, School of Environmental Science and Engineering, China

\begin{abstract}
Ammonia $\left(\mathrm{NH}_{3}\right)$ has played an essential role in meeting the increasing demand for food and the worldwide need of nitrogenous fertilizer since 1913. Unfortunately, the traditional Haber-Bosch process for producing $\mathrm{NH}_{3}$ from nitrogen $\left(\mathrm{N}_{2}\right)$ is a high energy-consumption process. Under ambient conditions catalytic reducing $\mathrm{N}_{2}$ to $\mathrm{NH}_{3}$ is an attractive and promising alternative approach which would emerge huge opportunity to directly provide nitrogenous fertilizers in agricultural fields as need in a distributed manner. In this review, some research findings showed alternative, available, sustainable $\mathrm{NH}_{3}$ production processes from $\mathrm{N}_{2}$ in the presence of electro-catalysts and photo-catalysts under ambient conditions.

Keywords: Catalyst; Nitrogen; Ammonia; Ambient condition
\end{abstract}

\section{Introduction}

As one of the most important chemicals to our planet, $\mathrm{NH}_{3}$ has played an essential role in meeting the growing demand for food and the worldwide need of nitrogenous fertilizer since 1913 [1]. The total worldwide $\mathrm{NH}_{3}$ production exceeded 140 million tons, and demand for $\mathrm{NH}_{3}$ continues to grow in 2014 [2], and about $80 \%$ of the $\mathrm{NH}_{3}$ product usually is used as nitrogenous fertilizer. Fritz Haber discovered that $\mathrm{NH}_{3}$ could be directly synthesized by reacting atmospheric $\mathrm{N}_{2}$ with hydrogen in the temperature range of $400-500^{\circ} \mathrm{C}$ and at pressures of 130-170bar [3], and Carl Bosch subsequently developed it on an industrial scale [4]. As the most important invention of the 20th century, the Haber-Bosch process, a thermo-chemical catalytic conversion technology, is a primary choice of industrial production of $\mathrm{NH}_{3}$ for human beings until now. According to the Haber-Bosch process, $\mathrm{NH}_{3}$ is produced from the reaction:

$$
\mathrm{N}_{2}+3 \mathrm{H}_{2} \leftrightarrow \mathrm{NH}_{3}
$$

The Haber-Bosch process reacts the pure feed gases at high temperatures and pressures, requiring energy input of around $485 \mathrm{~kJ}$ mol-1 of $\mathrm{N}_{2}$ and almost $2 \%$ of global energy consumption [5]. The high dissociation energy of triply bonded $\mathrm{N}_{2}$ molecule (911 kJ mol${ }^{-1}$ ) presents a significant activation energy barrier, however, the negative entropy $\left(\Delta \mathrm{H} 300=-46.35 \mathrm{~kJ} \mathrm{~mol}^{-1}\right)$ of the reaction dictates that $\mathrm{N}_{2}$ could be converted to $\mathrm{NH}_{3}$ at lower temperatures [6]. There are several advantages for $\mathrm{NH}_{3}$ synthesis at low temperatures $[7,8]$. Firstly, the reaction of producing $\mathrm{NH}_{3}$ from $\mathrm{N}_{2}$ with dihydrogen is spontaneous. Secondly, the proton conductivity of low-temperature electrolytes has more excellent behaves than the other temperature ones. Thirdly, the reaction kinetics of $\mathrm{NH}_{3}$ production processes is extremely slow when the operating temperatures are below $100^{\circ} \mathrm{C}$. It is Kordali et. al. [9] who firstly reported that $\mathrm{NH}_{3}$ was produced from $\mathrm{N}_{2}$ and water using a Nafion electrolyte at low temperature in 2000. In additional, it would be a key joint to build foundational principles of designing new efficient catalysts for sustainable $\mathrm{NH}_{3}$ synthesis production process. The new methods of catalyst design need us to understand the catalytic mechanisms by integrating theory and experiment of discovering the active, scalable, selective, long-lived efficient catalysts for sustainable $\mathrm{NH}_{3}$ synthesis.

Therefore, how to activate the $\mathrm{N} \equiv \mathrm{N}$ bond to produce $\mathrm{NH}_{3}$ with less fossil energy consumption is great opportunity and challenges for chemists. Although researchers tried to develop the artificial catalysts to facilitate the reaction at more ambient conditions and there are many new approaches, the nowadays used industrial catalysts are extremely similar to the original one discovered by Mittasch [10] in 1910s. In this review, some research findings showed alternative, available, sustainable $\mathrm{NH}_{3}$ production processes from $\mathrm{N}_{2}$ in the presence of electrocatalysts, photo-catalysts and analogous catalysts of nitrogenases metalloclusters under ambient conditions. 


\section{Discussion}

Recently, electro-catalysis depending on renewable electricity produced from renewable energy (such as wind or solar) has played an increasingly role in the $\mathrm{NH}_{3}$ synthesis at ambient temperature $\left(\mathrm{T}<100^{\circ} \mathrm{C}\right)[2,7,8,11]$. Some novel functional materials as catalysts used in typical $\mathrm{N}_{2}$ reductions were explored by researchers [12].

\section{Electro-Driven Catalytic Reducing $\mathbf{N}_{2}$ to $\mathbf{N H}_{3}$}

Under ambient conditions, Liu et al. [13,14] developed Sm1.5Sr0.5 $\mathrm{MO}_{4}(\mathrm{M}=\mathrm{Ni}, \quad \mathrm{Co}, \mathrm{Fe})$ and SmFe0.7Cu0.3-xNix$\mathrm{O} 3(\mathrm{x}=0-0.3)$ as electro-catalysts for $\mathrm{NH}_{3}$ synthesis with Nafion used as proton solid electrolyte. Such systems, while impressive in current efficiency, require careful control experiments due to low overall yields and observed ambient $\mathrm{NH}_{3}$ absorption by polymer electrolyte membranes. Further, researchers have taken their efforts to develop ideal electro-catalysts for improving $\mathrm{N}_{2}$ reduction rates and the $\mathrm{NH}_{3}$ yield. Impressively, SmFe0. $7 \mathrm{Cu} 0.1 \mathrm{Ni} 0.203$ showed the record-high $\mathrm{NH}_{3}$ production rate of $1.1 \times 10^{-8} \mathrm{~mol} \cdot \mathrm{s}^{-1} \cdot \mathrm{cm}^{-2}$ at $80^{\circ} \mathrm{C}$. The $\mathrm{NH}_{3}$ yield was up to $8.7 \times 10^{-9}$ $\mathrm{mol} \cdot \mathrm{s}^{-1} \cdot \mathrm{cm}^{-2}$ in the present of electro-catalyst SmBaCuMO5+i $(\mathrm{M}=\mathrm{Fe}, \mathrm{Co}, \mathrm{Ni})$ at $80^{\circ} \mathrm{C}$ and $2.5 \mathrm{~V}$ [15]. However, there are still big spaces to improve the $\mathrm{NH}_{3}$ yield which currently are not enough to the future industry application.

An alternative strategy would like to consider using metal nitrides as electro-catalyst cathodes for $\mathrm{N}_{2}$ reduction except pure metals. Respectively at potentials of $-0.76 \mathrm{~V}$ and $-0.51 \mathrm{~V}$, producing $\mathrm{NH}_{3}$ from $\mathrm{N}_{2}$ took place on the surface of $\mathrm{Zr} \mathrm{N}$ and $\mathrm{VN}$ as electro-catalyst cathodes which were not covered by adsorbed $\mathrm{H}$-atoms [16], the same to $\mathrm{Nb} \mathrm{N}$ and $\mathrm{CrN}$ [17]. The theoretical analysis of Abghoui et al. [18-20] predicted stable operation and Faraday Efficiency(FE) higher than 75\% for V, $\mathrm{Cr}, \mathrm{Nb}$ and $\mathrm{Zr}$ mono-nitrides at applied bias between 0.5 and $0.76 \mathrm{~V}$. Unfortunately, there would not be such nitride materials which were tested experimentally like above mentioned for $\mathrm{NH}_{3}$ synthesis [21]. Beside mono-nitrides, binary nitrides such as $\mathrm{Co}_{3} \mathrm{Mo}_{3} \mathrm{~N}$ are amongst the most active electro-catalysts for $\mathrm{NH}_{3}$ synthesis [22]. A thorough investigation of their electro-catalytic behaves should be performed in real $\mathrm{NH}_{3}$ synthesis situations.

These reports show that there was a universal phenomenon that these electro-catalysts often contain big proportions of oxides on their surfaces, which is harmful to keep their normal conductivity and could significantly reduce their catalytic efficiency. Actually, an ideal electro-catalyst should have the capacities of high catalytic activity and excellent electronic conductivity at ambient conditions and could suppress the hydrogen evolution reaction. The electro-catalytic $\mathrm{NH}_{3}$ synthesis is still under experiment stage, huge challenges are still faced the lack of the solid oxide electrolyte materials [23]. Future research should focus on theory-guided screening and discovery of new $\mathrm{NH}_{3}$ catalysts, as well as developing novel methods for $\mathrm{NH}_{3}$ synthesis at low temperatures and pressures. One important issue on the successful demonstration of $\mathrm{NH}_{3}$ being from reducing $\mathrm{N}_{2}$ and Overcoming $\mathrm{N}_{2}$ and $\mathrm{NH}_{3}$ contamination should be done with $15 \mathrm{~N}_{2}$ dinitrogen, FTIR analysis and choice of system materials.

\section{Photo-Driven Catalytic Reducing $\mathrm{N}_{2}$ to $\mathrm{NH}_{3}$}

With the global population increasing, the photon-driven $\mathrm{N}_{2}$ fixation technologies will become very critical to capture solar energy and produce nitrogenous fertilizers [24]. In the late 1970s, Schrauzer and Guth discovered that $\mathrm{TiO}_{2}$ powders doped with $\mathrm{Fe}_{2} \mathrm{O}_{3}$ could catalyze the reduction of $\mathrm{N}_{2}$ to $\mathrm{NH}_{3}$ under ambient conditions $[25,26]$. Since then, $\mathrm{TiO}_{2}$ became the workhorse photo-catalyst for subsequent studies, and $\mathrm{CuCl}, \mathrm{WO}$ and $\mathrm{FeOx}$ as possible photo-catalysts for $\mathrm{NH}_{3}$ synthesis have been investigated [27,28]. Maybe, surface oxygen defects of titanium metal caused by high temperatures could play an important role in the photo-driven catalytic reduction of $\mathrm{N}_{2}$ to $\mathrm{NH}_{3}$. Although there is not an insight regarding the atomic scale phenomena on photo-catalytic $\mathrm{N}_{2}$ reduction, the $\mathrm{TiO}_{2}$ crystal polymorph and its iron impurity concentration are identified to be the key factors to underlay photo-catalytic performance.

Co-catalysts, such as $\mathrm{Co}, \mathrm{Mo}, \mathrm{Ni}, \mathrm{Ru}$ and $\mathrm{Pt}$ dopants, have been added to the titanium-based materials for increasing the $\mathrm{NH}_{3}$ yield [24,29]. Transition metal dopants as electron sinks in titanium photo-catalysts could minimize the probability for carrier recombination to promote greater $\mathrm{NH}_{3}$ yields. Dopants inducing defect states could assist in charge separation of photogenerated electrons and holes but are not a part of the active site for $\mathrm{N}_{2}$ dissociation. Therefore, the conduction band position of photo-catalysts (Figure 1) should be more negative than the reduction potential of the $\mathrm{N}_{2}$ hydrogenation, as well as the valance band should be more positive than the oxygen evolution potential [30].

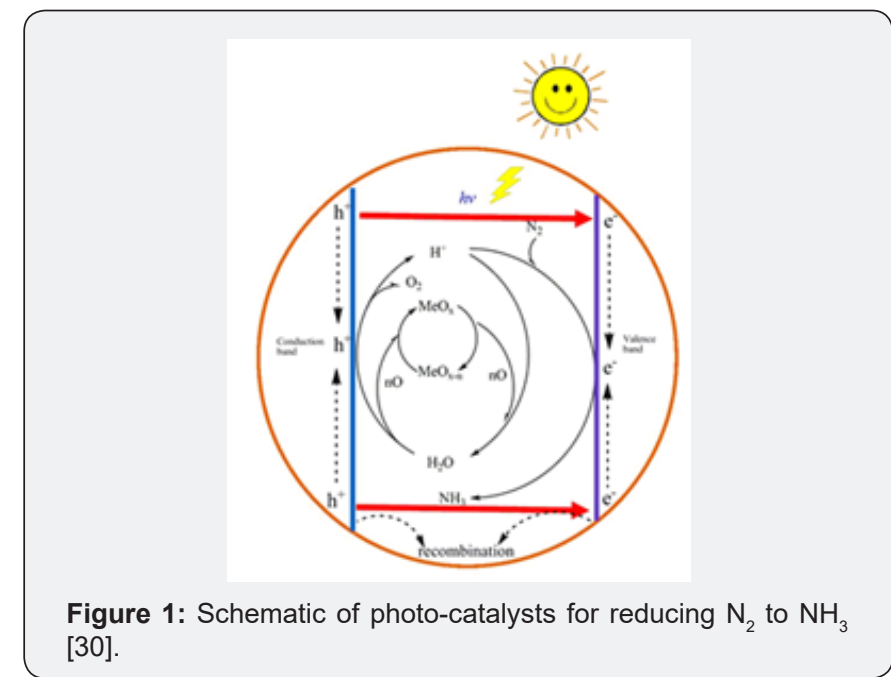

The partial current densities for photo-catalytic producing $\mathrm{NH}_{3}$ are lower 3 to 5 orders of magnitude than the other electrodriven $\mathrm{NH}_{3}$ production processes. To solve the problem, maybe the efficient photo-catalysts attached to electrodes would show us an amazing result of the higher $\mathrm{NH}_{3}$ yields. In additional, like 
electrochemical $\mathrm{NH}_{3}$ synthesis, photo-catalytic approaches must employ proper methods and controls.

\section{Conclusion}

Under ambient conditions, some seminal literatures have been reviewed on describing the electro-catalytic $\mathrm{NH}_{3}$ synthesis from commonly available feedstock such as purified $\mathrm{H}_{2}$ and $\mathrm{N}_{2}$. The electro-catalytic $\mathrm{NH}_{3}$ synthesis is still under experiment stage due to the lack of the suitable electrolyte materials as electro-catalysts with high catalytic activity, excellent electronic conductivity, and hydrogen evolution reaction. Transition metals which can achieve selective $\mathrm{N}_{2}$ reduction maybe are good choice for further researches. Additionally, it is with the high-energy UV light that photo-catalytic $\mathrm{NH}_{3}$ synthesis from $\mathrm{N}_{2}$ could overcome the $\mathrm{N} \equiv \mathrm{N}$ band energy barrier under ambient conditions. Currently, titanium oxide with transition metal dopants is a not bad choice in practice. Future studies should encourage investigating on how $\mathrm{N}_{2}$ reduction happen on the photo-catalysts with the application of modern computational and experimental techniques from molecular level viewpoint.

\section{Acknowledgment}

This work was supported by the China Scholarship Council (No. 201706565033).

\section{Conflict of Interest}

The author has declared that any economic interest or any conflict of interest exists.

\section{References}

1. T Kandemir, Schuster ME, Senyshyn A, Behrens M, Schlögl R (2013) The Haber-Bosch Process Revisited: On the Real Structure and Stability of "Ammonia Iron" under Working Conditions. Angew Chem Int Ed 52(48): 12723-12726.

2. Shipman MA, Symes MD (2017) Recent progress towards the electrosynthesis of ammonia from sustainable resources. Catalysis Today 286 57-68.

3. Haber F, Leiser R (1918) Method and apparatus for testing gases, US1269599A.

4. Carl Bosch (1932) The development of the chemical high-pressure method during the establishment of the new ammonia industry, Nobel Lectures:197-235.

5. Erisman JW, Bleeker A, Galloway J, Sutton M S(2007) Reduced nitrogen in ecology and the environment, Environmental Pollution 150(1): 140149.

6. Giddey S, Badwal SPS, Kulkarni A (2013) Review of electrochemical ammonia production technologies and materials. International journal of hydrogen energy 38: 14576-14594.

7. Garagounis I, Kyriakou V, Skodra A, Vasileiou E, Stoukides M (2014) Electrochemical synthesis of ammonia in solid electrolyte cells. Front Energy Res 2: 1-10.

8. IA Amar, R Lan, CTG Petit SW Tao (2011) Solid-state electrochemical synthesis of ammonia: a review J Solid State Electro chem 15: 18451860.

9. Kordali V, Kyriakou G, Lambrou C (2000) Electrochemical synthesis of ammonia at atmospheric pressure and low temperature in a solid polymer electrolyte cell. Chem Commum 17(2000): 1673-1674.
10. Schlögl R (2003) Catalytic Synthesis of Ammonia-A "Never-Ending Story"? Angew Chem Int Ed Engl 42(18): 2004-2008.

11. Giddey S, Badwal SPS, Kulkarni A (2013) Review of electrochemical ammonia production technologies and materials, International J. Hydrogen Energy 38: 14576-14594.

12. Kyriakou V, Garagounis I, Vasileiou E, Vourros A, Stoukides M (2017) Progress in the Electrochemical Synthesis of Ammonia, Catalysis Today 286: 2-13.

13. Xu GC, Liu RQ, Wang J (2009) Electrochemical synthesis of ammonia using a cell with a Nafion membrane and $\mathrm{SmFe} 0.7 \mathrm{Cu} 0.3-\mathrm{xNi}$ xO3 $(\mathrm{x}=0-0.3)$ cathode at atmospheric pressure and lower temperature. Sci China Ser B: Chem 52(8): 1171-1175.

14. Liu RQ , Xu G (2010) Comparison of Electrochemical Synthesis of Ammonia by Using Sulfonated Polysulfone and Nafion Membrane with Sm1.5Sr0.5Ni04. Chin J Chem 28(2): 139-142.

15. Hang ZF, Zhong ZP, Liu RQ (2010) Cathode catalysis performance of SmBaCuMO5 $(\mathrm{M}=\mathrm{Fe}, \mathrm{Co}, \mathrm{Ni})$ in ammonia synthesis, Journal of Rare Earths 28(4): 556-559.

16. Abghoui Y, Garden AL, Hlynsson VF, Björgvinsdóttir S, Ólafsdóttir H, Skúlason E (2015) Enabling electrochemical reduction of nitrogen to ammonia at ambient conditions through rational catalyst design, Phys Chem Chem Phys 17: 4909-4918.

17. Abghoui Y, Garden AL, Howalt JG, Vegge T, Skúlason E (2016) Electroreduction of Nitrogen to Ammonia at Ambient Conditions on Mononitrides of Zr, Nb, Cr, and V: A DFT Guide for Experiments, ACS Catal 6(2): 635-646.

18. Ivana M, Fernando HG, Neil JH (2014) Electro-reduction of nitrogen on molybdenum nitride: structure, energetics, and vibrational spectra from DFT, Phys Chem Chem Phys 16: 3014-3026.

19. Hlynsson VF, Skúlason E, Garden AL (2014) A systematic, firstprinciples study of the structural preference and magnetic properties of mononitrides of the d-block metals. J Alloys Compd 603(2014): 172179.

20. Michalsky R, Avram AM, Peterson BA, Pfromm PH, Peterson AA (2015) Chemical looping of metal nitride catalysts: low-pressure ammonia synthesis for energy storage, Chem Sci 6(7): 3965-3974.

21. Michael A, Shipman, Mark D, Symes (2017) Recent progress towards the electrosynthesis of ammonia from sustainable resources, Catalysis Today 286: 57-68.

22. Jacobsen CJH (2000) Novel class of ammonia synthesis catalysts Chem Commun 1057-1058.

23. Xinghua Guo, Yunpei Zhu, Tianyi Ma (2017) Lowering reaction temperature: Electrochemical ammonia synthesis by coupling various electrolytes and catalysts, Journal of Energy Chemistry 26:1107-1116.

24. Andrew J, Medford, Marta C, Hatzell (2017) Photon-Driven Nitrogen Fixation: Current Progress, Thermodynamic Considerations, and Future Outlook, ACS Catal 7: 2624-2643.

25. Schrauzer GN, Guth TD (1977) Photolysis of Water and Photoreduction of Nitrogen on Titanium Dioxide. J Am Chem Soc 99(22): 7189-7193.

26. Schrauzer G, Guth T, Palmer M (1979) In Solar Energy: Chemical Conversion and Storage. J Nitrogen reducing solar cells, The Humana Press: Clifton NJ: 261-269.

27. Yamazoe S, Yasuyuki M, Kentaro T, Yutaka H, Tetsuya S, et al. (2008) Promotion effect of tungsten oxide on photo-assisted selective catalytic reduction of NO with $\mathrm{NH}_{3}$ over TiO2, Applied Catalysis B: Environmental 83(1-2): 123-130.

28. Tennakone K, Punchihewa S, Tantrigoda R (1989) Nitrogen photoreduction with cuprous chloride coated hydrous cuprous oxide, Solar Energy Materials 18(3-4): 217-221. 
29. Ranjit K, Varadarajan T, Viswanathan B (1996) Photocatalytic reduction of dinitrogen to ammonia over noble-metal-loaded $\mathrm{TiO}_{2}$, Journal of Photochemistry and Photobiology A: Chemistry 96(1-3): 181-185.
30. Jianjun Yang (2018) Progress of metal oxide(sulfide) based photocatalytic materials for reducing nitrogen to ammonia. J Chem 2018: 1-8.

\section{Your next submission with Juniper Publishers will reach you the below assets}

- Quality Editorial service

- Swift Peer Review

- Reprints availability

- E-prints Service

- Manuscript Podcast for convenient understanding

- Global attainment for your research

- Manuscript accessibility in different formats ( Pdf, E-pub, Full Text, Audio)

- Unceasing customer service

Track the below URL for one-step submission https://juniperpublishers.com/online-submission.php 